\title{
Technological Characterization of Cupressus spp. Wood
}

\author{
Esmeralda Yoshico Arakaki Okino, Marcos Antonio Eduardo Santana, \\ Marcus Vinicius da Silva Alves, Júlio Eustáquio de Melo, \\ Vera Terezinha Rauber Coradin, Mário Rabelo de Souza, \\ Divino Eterno Teixeira, Maria Eliete de Sousa
}

Serviço Florestal Brasileiro - SFB, Laboratório de Produtos Florestais - LPF

\begin{abstract}
The objectives of the present study were to determine anatomical characteristics, mechanical properties and natural durability to two fungi types [Gloeophyllum trabeum (Persoon ex Fries) Murrill and Trametes versicolor (Linnaeus ex Fries)Pilat] for cypress wood (Cupressus spp.). The wood has straight grain, brown to white color, medium texture, and moderate luster. It also showed medium to low density, low shrinkage, and moderate dimensional stability. Lignin content was relatively high, whereas extractive content was low. Cupressus spp. showed static bending properties of $4.1 \mathrm{GPa}$ for modulus of elasticity; $91.0 \mathrm{MPa}$ for modulus of rupture; 1.8 MPa for internal bond; and 6357 and $4039 \mathrm{~N}$ for end and side Janka hardness, respectively. All mechanical properties, in air-dry condition, were similar to those described to cypresses and some Amazonian hardwood species. Cypress wood was ranked as highly resistant to the brown-rot fungus Gloeophyllum trabeum and to the white-rot fungus Trametes versicolor, making it suitable for interior and exterior uses and high humidity environment.
\end{abstract}

Keywords: mechanical properties, anatomical characteristics, cypress, natural durability.

\section{Caracterização Tecnológica da Madeira de Cupressus spp.}

\section{RESUMO}

Os objetivos deste estudo foram determinar as características anatômicas, propriedades mecânicas e a durabilidade natural da madeira de cipreste (Cupressus spp.) exposta ao fungo de podridão-parda, o Gloeophyllum trabeum (Persoon ex Fries) Murrill, e ao fungo de podridãobranca, o Trametes versicolor (Linnaeus ex Fries) Pilat. A madeira tem grã direita, cor branca a marrom, textura média e brilho moderado. Apresenta de média a baixa densidade, baixa contração e moderada estabilidade dimensional. O teor de lignina foi relativamente alto, enquanto a de extrativos foi baixa. A madeira de Cupressus spp. apresentou 4,1 GPa para o módulo de elasticidade; 91,0 MPa para o módulo de ruptura; 1,8 MPa para a ligação interna e 6357; e $4039 \mathrm{~N}$ para a dureza Janka de topo e lateral, respectivamente. Todas as propriedades mecânicas, na condição seca, foram semelhantes aos descritos para ciprestes e algumas espécies de madeira da Amazônia. A madeira de cipreste foi classificada como altamente resistente aos fungos de podridão-parda Gloeophyllum trabeum e de podridão branca Trametes versicolor, tornando-a adequada para uso interior e exterior e meio ambiente de alta umidade.

Palavras-chave: propriedades mecânicas, características anatômicas, cipreste, durabilidade natural. 


\section{INTRODUCTION}

The two most widespread genera of the Cupressaceae family are Juniperus and Cupressus. At present, there are more than 70 species of Juniperus, mostly in North America, Middle East Asia, and Europe. The distribution of the Cupressus deserves mention: most species, about ten, grow in the Southern regions of North America, while a few others, about four species, grow in South Asia (Greguss, 1955).

There used to be few articles related to cypress wood, but in the last decade, there have been quite a number of articles reporting the cypress wood properties (Pereira \& Higa, 2003; Okino et al., 2006); physical and mechanical properties and decay resistance of particleboards, flakeboards and cement-bonded panels (Okino et al., 2004, 2005), physical and mechanical properties of OSB, natural durability and post-thermal treatment (Okino et al., 2008, 2009, 2007a, 2007b); wood color (Okino et al., 2009); and evaluation of wood chemical constituents using CP/MAS ${ }^{13} \mathrm{C}$ NMR and HPLC techniques (Okino et al., 2008, 2010).

Haslett (1986) published details of the properties and potential uses of Cupressus macrocarpa, C. lusitanica, Chamaecyparis lawsoniana and Cupressocyparis leylandii. Apart from difficulties with drying, particularly for C. macrocarpa, these species are relatively easy to process. The species have similar wood characteristics: attractive grain, medium to low density, low shrinkage, and excellent stability, and most important, high natural durability. Cypress wood is highly suitable for use in exterior joinery, weatherboards, and boat-building. Although it is currently used in furniture, the low surface hardness of cypress wood detracts it for this use. Shukla \& Sangal (1986) tested physical and mechanical properties of ten exotic timber species, among them, Cupressus lusitanica; they concluded that these exotic species are weak in strength as compared to Tectona grandis. Kothiyal et al. (1997), classified Cupressus goveniana as a moderately heavy, weak, not tough and soft timber, which should be used for crates and packing. Following the same study, Kothiyal et al. (1998) reported the wood quality of eighteen-year- old Cupressus lusitanica, and the timber was found to be quite knotty and also a possessing compression wood. Data shows that the timber is weak in strength properties compared to Tectona grandis and Cedrus deodora.

Cupressus lusitanica Mill. is a multipurpose tree species with a high potential for wood production in Brazil, in a cool climate with high humidity. The annual increment ranges approximately from 20 to $35 \mathrm{~m}^{3} /$ ha year (Foelkel \& Zvinakevicius, 1978).

Clark (1969) established an estimate decay resistance of heartwood of Guatemalan cypress (Cupressus lusitanica Mill.) against the brown-rot fungus (Lenzites trabea) and the white-rot fungus (Poria monticola); 2 and 31\% weight loss was found, respectively.

A focused and detailed study is necessary, once cypress wood is well known overseas as a homogeneous plantation with high quality wood yield and a large spectrum of end uses. Moreover, Brazil has little information with reference to genetic and silvicultural improvements, as well as to basic technological data.

The objectives of the present study were to determine the anatomical characteristics, chemical results, mechanical properties and natural durability of cypress wood (Cupressus spp.) to two types of fungus [Gloeophyllum trabeum (Persoon ex Fries) Murrill and Trametes versicolor (Linnaeus ex Fries) Pilat].

\section{MATERIAL AND METHODS}

Logs of Cupressus spp., obtained from 20-30-years-old trees of unknown progeny, were collected in Brasília - DF, Brazil. Cross sectional discs were cut to make anatomical and chemical characterization. The presence of knots and defects was very carefully avoided while preparing small clear specimens for testing. Samples from random heights along the trunk were prepared to evaluate the physical and mechanical properties, as well as the natural durability to two wood-destroying fungi [Gloeophyllum trabeum (Persoon ex Fries) Murrill and Trametes versicolor (Linnaeus ex Fries)Pilat]. 


\subsection{Anatomical characterization}

\subsubsection{General characteristics}

The general characteristics were based on Coradin \& Muñiz (1991). All characteristics analyzed were the average of three observations and the methodology used is described below:

a) Heartwood/Sapwood: Distinction of heartwood and sapwood was verified by means of the difference in color and classified as: distinct and indistinct.

b) Color: It is very subjective and it is one of the main characteristics used to identify and to define end uses of timber, mainly when associated with texture and figures. Color was observed on the longitudinal tangential surface of the $50 \times 20 \times$ $150 \mathrm{~mm}$ air-dried samples of fresh smoothed surface. Color determination was made by comparison with a standardized scale for soils, the Soil Color Charts (Munsell, 1975), which designate the colors by means of a notation comprising two complementary systems, that is, the name of the so-called color, followed by a code number on the scale corresponding to the color. Another more specific method to find the wood color was based on the CIE La*b* Color System, where measurements were taken on several freshly cut places using a Datacolor Microflash V.4.1 spectrocolorimeter. The illuminant was a D65, with an angle of 10 at $25^{\circ} \mathrm{C}$ room temperature and $(65 \pm$ $2 \%)$ of relative humidity. The measurements were taken in 10 places covering an area of $50 \mathrm{~mm}^{2}$.

c) Growth rings: The growth rings were observed with the naked eye in sanded discs and classified by their visibility as: distinct, slightly distinct and indistinct.

d) Grain: The grain was verified in $60 \times 50 \mathrm{x}$ $200 \mathrm{~mm}$ samples, along the radial and tangential longitudinal planes. For the grain observation, the samples were split with a mallet blow on a cutting tool along the radial and tangential direction, as indicated by Jane (1970). The grain was classified as: straight, cross, interlocked, bending, helical and wavy.

e) Texture: A characteristic that refers to the distinction, width, and regularity of growth ring, observed on the transversal section. Texture type: Thin: growth rings slightly distinct to indistinct;
Medium: growth rings distinct and narrow; Thick: growth rings well distinct and wide.

f) Figure: It was observed on the sanded surface with dimensions of $50 \times 150 \mathrm{~mm}$ along the radial and tangential longitudinal sections. The figure of the wood is considered to be the aspects coming from the color differences caused by growth rings, rays with channels, orientation, biological staining agents, knots, and difference in color inside the growth rings.

g) Luster: This characteristic was verified in the sample and was classified as presence or absence of luster as: no luster, medium luster, or high luster.

h) Odor: No specific methodology was used for this characteristic, since it was detected during observations of the general characteristics, and classified as: perceptible or not perceptible.

i) Hardness: Subjective data determined by manual pressure exerted with cutting tools across the fibers, with the wood being classified as: soft, moderately hard and hard.

\subsubsection{Macroscopic description}

Based on Coradin \& Muñiz (1991), wood samples of $20 \times 20 \mathrm{~mm}$ of transversal section and $30 \mathrm{~mm}$ length were taken from disc, polished in microtome and well oriented to transversal, tangential and radial longitudinal sections, for best visibility of the wood elements.

\subsection{Chemical characterization}

Three discs were randomly chosen and used to determine the lignin content, holocellulose, cellulose and extractives of Cupressus spp. Specimens were sampled to determine lignin and extractives according to the "Technical Association of Pulp and Paper Industry" standard (Tappi, 1996). The holocellulose and $a$-cellulose contents were determined according to Laboratory Instructions, Wood chemistry - WPS 332-L from Research Center of Wood and Paper Department of North Carolina State University (NCSU) (North..., 1989).

\subsubsection{Preparation of wood samples for chemical analysis}

Wood for chemical analysis was ground in a Thomas-Wiley Model 4 mill to pass a 35 mesh 
screen. The material to be extracted was inserted into the extraction thimble and placed in the Soxhlet device using a mixture of toluene-ethanol at 2:1 (v/v), followed by ethanol refluxing and later with distilled water, according to TAPPI - T264 om-82 standard (Tappi, 1996a).

\subsubsection{Acid-insoluble lignin}

The carbohydrates in cypress wood were hydrolyzed with sulfuric acid; the acid-insoluble lignin was filtered off, dried, and weighed according to TAPPI - T222 om-88 standard (Tappi, 1996b).

\subsubsection{Quantitative isolation of holocellulose}

The holocellulose content was determined through a lignin degradation process in the presence of sodium chlorite and acetic acid. The holocellulose yield was based on the original dry wood.

\subsubsection{Quantitative determination of alpha- cellulose and hemicellulose}

The alpha-cellulose is the insoluble residue obtained when holocellulose is treated with $17.5 \%$ sodium hydroxy; it is considered to represent the undergraded, higher-molecular-weight cellulose in the sample. The soluble portion is reported as hemicellulose and it is obtained from the difference of holocellulose and $\alpha$-cellulose. The residual weight was reported as the percentage amount of the wood.

\subsubsection{Extractive content}

The extractive content was determined according to TAPPI T204 om-88 standard (Tappi, 1996c) with some modifications. From the air-dry sample, a specimen equivalent to $(2.0 \pm 0.1) \mathrm{g}$ of wood was weighed in a tared extraction thimble. The extraction thimble and specimen were placed in position in the Soxhlet device. The extraction flask was filled with $200 \mathrm{~mL}$ of ethanol-toluene mixture at 1:2 (v/v) and connected to the extraction device in an adjusted boiling rate and time of extraction. The solvent was then evaporated to near dryness. The flask was dried in an oven for 1 hour at $(115 \pm 5)^{\circ} \mathrm{C}$ cooled in a desiccator, and weighed to the nearest $0.1 \mathrm{mg}$.

\subsection{Determination of physical and mechanical properties}

Physical and mechanical properties were determined according to ASTM D143-94 (Associação..., 1994) standard, using small clear defect-free specimens. Densities were determined using a water displacement system under the following conditions: basic (oven-dry weight/green volume), air dry (weight/volume both oven-dried), and green density (weight/volume both in green condition). The tangential, radial and volumetric shrinkage was determined based on moisture content change from saturation fiber point to the oven-dry condition. Mechanical properties of air dry specimens were tested in an INSTRON 1127 universal testing machine.

\subsection{Decay rating testing}

The sound blocks were tested according to ASTM D 2017 (Associação..., 2005) by using pure cultures of decay fungi: a brown-rot fungus, Gloeophyllum trabeum (Persoon ex Fries) Murrill and a white-rot fungus, Trametes versicolor (Linnaeus ex Fries) Pilat. Tests were carried out in wide-mouth, screw-topped, round bottles, each half filled with soil with a $\mathrm{pH}$ of 5.6. Water was added to the soil until a moisture content of $42-45 \%$. Feeding blocks of Pinus spp. measuring $3 \times 29 \mathrm{~mm}$ and $35 \mathrm{~mm}$ grainwise were used for brown-rot fungus and blocks of the same dimensions of Cecropia spp. were used for white-rot fungus. A feeder block was placed and pressed on the surface of the soil on each bottle and the system was then sterilized ( 1 hour at $120^{\circ} \mathrm{C}$ ) and inoculated with the test fungi. The test specimens were previously sterilized in closed bottles for 20 minutes at $120{ }^{\circ} \mathrm{C}$ and then placed one in each bottle. A total of twelve replications, blocks measuring $25 \times 25 \mathrm{~mm}$ and $9 \mathrm{~mm}$ grainwise were tested for each tree. The bottles were loosely capped to permit air exchange and then incubated for 12 weeks in a climatized room maintained at $(27 \pm 1)^{\circ} \mathrm{C}$ and $(70 \pm 4) \%$ relative humidity. At the end of the incubation period, the wood specimens were removed, brushed, and dried to constant weight. The weight losses percentage was calculated based on the blocks weights before and after the fungi exposure. This percentage provided a measure of the relative decay susceptibility or, the decay resistance of the wood sample. After testing the blocks were rated according to the Table 1 . 
Table 1. Decay resistance expressed as either weight loss or residual weight according to ASTM D 2017 standard (Associação..., 2005).

Tabela 1. Resistência à degradação expresso como perda de massa ou massa residual de acordo com a norma ASTM D 2017 (Associação..., 2005).

\begin{tabular}{ccc}
\hline Average weight loss (\%) & Average residual weight (\%) & Resistance classes indicated \\
\hline 0 to 10 & 90 to 100 & Highly resistant \\
11 to 24 & 76 to 89 & Resistant \\
25 to 44 & 56 to 75 & Moderately resistant \\
45 or above & 55 or less & Slightly resistant or nonresistant \\
\hline
\end{tabular}

\section{RESULTS AND DISCUSSION}

\subsection{Anatomical characterization}

\subsubsection{Material description}

Common name: cypress

Current botanical name: Cupressus spp.

Family: Cupressaceae

Other vernacular names in Brazil: "ciprestecomum", "cipreste-piramidal" (Camargos et al., 2001).

Area of collection: Brasília, DF

\subsubsection{General characteristics of the wood}

Heartwood/Sapwood: slightly distinct to distinct.

Color: brown moderate pale (10YR 8/3) to white (10YR 8/2), or according to Datacolor Microflash $200 \mathrm{~d}$ Spectophotometer the values of variables $\mathrm{L}, \mathrm{a}^{*}$, and $\mathrm{b}^{\star}$ were 73.15, 8.19, 22.21 (white), respectively.

Growth rings: distinct and irregular.

Grain: straight.

Texture: medium

Tangential figure: "V" shape and longitudinal strips due to growth rings.

Radial figure: longitudinal strips due to growth rings and dark spots because of knots.

Luster: moderate.

Odor: agreeable characteristic smell.

Hardness: soft.

\subsubsection{Macroscopic description}

Radial parenchyma (rays): visible trough $10 \mathrm{X}$ lens; but difficult in transversal section, and slight visible, even through $10 \mathrm{X}$ lens, in tangential section.
Growth rings: distinct to the naked eyes.

Transition between earlywood and latewood: abrupt.

\subsection{Chemical characterization}

Average values of chemical components of the cypress wood are shown in Table 2. The amount of lignin and extractive contents were homogeneous among the trees. The sum of the chemical compounds of the wood exceeds 100, being difficult to separate these elements of the wood. Results of holocellulose and lignin contents agree with those presented by Foelkel \& Zvinakevicius (1978), who evaluated the cypress quality for cellulose kraft production. Extractives were just about the same amount as observed by Guha et al. (1969) to C. cashmeriana (4.5\% alcohol-benzene), higher than Guha et al. (1971) to C. lusitanica (1.8\% alcohol-benzene) and lower than Pereira \& Higa (2003) to C. lusitanica (7.5\% total extractives).

\subsection{Physical and mechanical properties of cypress wood}

Mean values of physical properties of cypress wood are shown in Table 3 . The cypress basic density mean value $\left(0.52 \mathrm{~g} / \mathrm{cm}^{3}\right)$ was higher than $0.41 \mathrm{~g} / \mathrm{cm}^{3}$ reported by Okino et al. (2006) and Pereira \& Higa (2003). This study corroborated the results reported by Paraskevopoulou (1991), where specific gravity, based on means from three different areas of collection, ranged from 0.447 to 0.510 and individual tree values ranged from 0.396 to 0.594 to Cupressus sempervirens var. horizontalis Gord. The anisotropy of approximately 1.6 mean value was homogeneous in the three previous studies.

Results of the strength properties, in drycondition (12\% moisture content), are shown in 
Table 2. Chemical components of cypress wood average values.

Tabela 2. Valores médios dos componentes químicos da madeira de cipreste.

\begin{tabular}{|c|c|c|c|c|c|}
\hline \multirow{2}{*}{ Material } & \multicolumn{5}{|c|}{ Components (\%) } \\
\hline & Extractives $^{a}$ & Klason lignin ${ }^{\mathrm{b}}$ & Holocellulose $^{\mathrm{b}}$ & Hemicellulose $^{c}$ & Cellulose $^{\mathrm{b}}$ \\
\hline Sample-A & 4.0 & 33.5 & 72.3 & 25.0 & 47.3 \\
\hline Sample-B & 4.1 & 33.7 & 72.1 & 25.1 & 47.0 \\
\hline Sample-C & 4.1 & 33.4 & 71.1 & 23.0 & 48.1 \\
\hline Means $^{\mathrm{d}}$ & $4.1(0.1)^{\mathrm{e}}$ & $33.5(0.1)$ & $71.8(0.6)$ & $24.4(1.2)$ & $47.5(0.6)$ \\
\hline
\end{tabular}

${ }^{a}$ Based on oven dry-weight of wood. ${ }^{b}$ Based on extractive-free dry-wood. ${ }^{c}$ Difference between holocellulose and cellulose. ${ }^{\mathrm{d}}$ Mean values of three replicates. ${ }^{e}$ Number in parentheses are standard deviations.

Table 3. Means for physical properties of Cupressus spp. in air dry condition (moisture content of 12\%).

Tabela 3. Valores médios de propriedades físicas do Cupressus spp., em base seca (teor de umidade de 12\%).

\begin{tabular}{|c|c|c|c|c|c|c|c|c|c|c|c|c|c|c|c|}
\hline \multirow{3}{*}{ Tree } & \multicolumn{7}{|c|}{ Density $\left(\mathrm{g} / \mathrm{cm}^{3}\right)$} & \multicolumn{6}{|c|}{ Shrinkage - Green to oven dried (\%) } & \multirow{2}{*}{\multicolumn{2}{|c|}{$\begin{array}{c}\text { Ratio of } \\
\text { shrinkage } \\
\text { T/R }\end{array}$}} \\
\hline & \multirow[t]{2}{*}{$\mathbf{n}$} & \multicolumn{2}{|c|}{ Dry } & \multicolumn{2}{|c|}{$\begin{array}{c}\text { Green } \\
\text { (Saturated) }\end{array}$} & \multicolumn{2}{|c|}{ Basic } & \multicolumn{2}{|c|}{$\begin{array}{l}\text { Tangential } \\
\text { (T) }\end{array}$} & \multicolumn{2}{|c|}{$\begin{array}{c}\text { Radial } \\
\text { (R) }\end{array}$} & \multicolumn{2}{|c|}{$\begin{array}{c}\text { Volumetric } \\
\text { (V) }\end{array}$} & & \\
\hline & & $\mathbf{M}$ & SD & $\mathbf{M}$ & SD & $\mathbf{M}$ & SD & $\mathbf{M}$ & SD & $\mathbf{M}$ & SD & $\mathbf{M}$ & SD & $\mathbf{M}$ & SD \\
\hline A & 2 & 0.54 & 0.04 & 0.82 & 0.04 & 0.49 & 0.03 & 6.2 & 0.3 & 4.7 & 0.4 & 9.9 & 0.4 & 1.3 & 0.0 \\
\hline B & 2 & 0.60 & 0.05 & 0.83 & 0.04 & 0.53 & 0.03 & 5.9 & 1.0 & 3.3 & 0.7 & 11.4 & 2.2 & 1.8 & 0.6 \\
\hline C & 4 & 0.57 & 0.03 & 0.89 & 0.04 & 0.51 & 0.03 & 6.5 & 0.5 & 3.7 & 0.3 & 10.1 & 0.1 & 1.8 & 0.1 \\
\hline D & 4 & 0.62 & 0.04 & 0.93 & 0.07 & 0.57 & 0.04 & 3.7 & 0.2 & 2.6 & 0.2 & 7.7 & 0.3 & 1.4 & 0.1 \\
\hline $\mathrm{E}$ & 5 & 0.63 & 0.09 & 0.86 & 0.07 & 0.57 & 0.07 & 5.6 & 0.4 & 4.0 & 0.5 & 9.1 & 0.7 & 1.4 & 0.2 \\
\hline $\mathrm{F}$ & 7 & 0.60 & 0.09 & 0.93 & 0.08 & 0.55 & 0.08 & 4.8 & 0.9 & 3.4 & 1.1 & 8.0 & 1.1 & 1.4 & 0.3 \\
\hline G & 6 & 0.44 & 0.02 & 0.82 & 0.07 & 0.40 & 0.02 & 5.2 & 0.8 & 3.0 & 0.4 & 7.9 & 0.7 & 1.7 & 0.1 \\
\hline $\mathrm{H}$ & 5 & 0.55 & 0.01 & 0.88 & 0.09 & 0.50 & 0.01 & 5.8 & 0.5 & 4.3 & 0.5 & 9.6 & 0.2 & 1.3 & 0.3 \\
\hline
\end{tabular}

$\mathrm{n}$ - Number of small clear specimens. M - Mean values. SD - Standard deviation.

Table 4. The variation coefficient of some mechanical properties in this study was higher than the required in the Wood Handbook (United..., 1987), but this deviation can be explained by some not visible internal defects in the small clear specimens. The mean values of stress at proportional limit of elasticity (35.5 MPa) and compression strength parallel to the grain $(35.6 \mathrm{MPa})$ were similar. The mean value of modulus of elasticity - MOE (3122 MPa) was lower than $6965 \mathrm{MPa}$ reported by Okino et al. (2006). On the other hand, end and side Janka Hardness mean values were higher than those reported by Okino et al. (2006).

Table 5 lists physical and mechanical properties of the studied cypress, which showed the lowest and highest basic densities, and were compared to some Amazonian hardwoods, mainly those that have shown basic density in the range of 0.39 to $0.52 \mathrm{~g} / \mathrm{cm}^{3}$. The cypress that showed the highest basic density also showed the highest Janka Hardness among all cypress listed on this table. The MOR and compression strength parallel mean values, of the better performance cypress, can be compared to' fava-arara', 'faveira', 'burra-leiteira' and 'açacu', all light color wood species. At first look, cypress wood can be used for paneling, toys, furniture, framework, carpentry work, boats and light construction, the same end-uses applied to this group of woods. According to these groups, the cypress wood is an excellent timber to be introduced as new or replacement species with great potential. The statement of the presence of knots with an average distance of $(6.22 \pm 2.96) \mathrm{cm}$ between two adjacent knots makes it difficult to obtain timber of proper size for industrial and constructional applications (Kothiyal et al., 1997). It is not applicable to all cypress species because Carvalho (1954) testing Cupressus lusitanica observed that, if suitable management is applied and pruning is periodically done since early years, the tree has a strong aptitude for cicatrisation, reducing the knots and other defects in the timber. 
Table 4. Means for mechanical properties, in dry-condition (12\% moisture content), of Cupressus spp. wood.

Tabela 4.Valores médios de propriedades mecânicas, na condição seca ( $12 \%$ de teor de umidade), de Cupressus spp.

\begin{tabular}{|c|c|c|c|c|c|c|c|c|c|c|c|}
\hline \multirow{3}{*}{ Tree } & \multirow{3}{*}{$\mathbf{n}$} & \multicolumn{6}{|c|}{ Static Bending } & \multicolumn{4}{|c|}{$\begin{array}{c}\text { Compression Strength Paralle } \\
\text { to the grain }\end{array}$} \\
\hline & & \multicolumn{2}{|c|}{ MOR (MPa) } & \multicolumn{2}{|c|}{ MOE (MPa) } & \multicolumn{2}{|c|}{ SPL (MPa) } & \multirow{2}{*}{ Tree } & \multirow{2}{*}{$\mathbf{n}$} & \multicolumn{2}{|c|}{ (MPa) } \\
\hline & & $\mathbf{M}$ & SD & $\mathbf{M}$ & SD & $\mathbf{M}$ & SD & & & $\mathbf{M}$ & SD \\
\hline A & 1 & 72 & - & 3475 & - & 43 & - & A & 1 & 33 & - \\
\hline B & 1 & 47 & - & 3758 & - & 37 & - & - & - & - & - \\
\hline $\mathrm{C}$ & 2 & 57 & 12 & 2340 & 825 & 26 & 5 & $\mathrm{C}$ & 2 & 31 & 1 \\
\hline $\mathrm{D}$ & 1 & 27 & - & 2185 & - & 20 & - & $\mathrm{D}$ & 2 & 35 & 8 \\
\hline $\mathrm{E}$ & 2 & 91 & 17 & 4148 & 474 & 42 & 11 & $\mathrm{E}$ & 2 & 41 & 5 \\
\hline $\mathrm{F}$ & 1 & 87 & - & 5431 & - & 48 & - & - & - & - & - \\
\hline G & 2 & 68 & 3 & 2888 & 411 & 35 & 3 & - & - & - & - \\
\hline $\mathrm{H}$ & 1 & 80 & - & 4473 & - & 33 & - & $\mathrm{H}$ & 2 & 38 & 5 \\
\hline \multicolumn{8}{|c|}{ Janka Hardness } & \multicolumn{4}{|c|}{$\begin{array}{c}\text { Tensile strength Perpendicular } \\
\text { to the grain }\end{array}$} \\
\hline \multirow{2}{*}{ Tree } & \multirow{2}{*}{$\mathbf{n}$} & \multicolumn{3}{|c|}{ End $(\mathbf{N})$} & \multicolumn{3}{|c|}{ Side $(\mathbf{N})$} & \multirow{2}{*}{ Tree } & \multirow{2}{*}{$\mathbf{n}$} & \multicolumn{2}{|c|}{ (MPa) } \\
\hline & & $\mathbf{M}$ & & & $\mathbf{M}$ & & & & & $\mathbf{M}$ & SD \\
\hline A & 2 & 3989 & & & 3353 & & & A & 3 & 2.4 & 0.8 \\
\hline $\mathrm{B}$ & 2 & 7269 & & & 6289 & & & $\mathrm{~B}$ & 2 & 1.9 & 1.1 \\
\hline $\mathrm{C}$ & 2 & 6923 & & & 5399 & & & $\mathrm{C}$ & 2 & 2.6 & 0.3 \\
\hline $\mathrm{D}$ & 2 & 5565 & & & 4624 & & & $\mathrm{D}$ & 2 & 2.1 & 0.2 \\
\hline $\mathrm{E}$ & 2 & 6357 & & & 4039 & & & $\mathrm{E}$ & 2 & 1.8 & 0.4 \\
\hline $\mathrm{F}$ & 2 & 6435 & & & 4398 & & & $\mathrm{~F}$ & 2 & 2.3 & 0.2 \\
\hline G & 2 & 4631 & & & 2381 & & & G & 2 & 1.7 & 0.3 \\
\hline $\mathrm{H}$ & 2 & 4933 & & & 3211 & & & $\mathrm{H}$ & 2 & 1.7 & 0.0 \\
\hline
\end{tabular}

$\mathrm{n}$ - Number of small clear specimens. M - Mean values, SD - Standard deviations. MOR = modulus of rupture; MOE = modulus of elasticity; SPL = Fiber Stress at elastic limit.

\subsection{Natural durability}

Weight loss percentage after 12 weeks of exposure is shown in Table 6. Both fungi failed to attack the samples. At the end of this period, some bottles resulted in the production of fruiting bodies in the surrounding areas. Cypress wood showed no weight loss after 12 weeks of exposure to T. versicolor and it was classed as "highly resistant". Our results for cypress wood are similar to those found for other species of the same family Cupressaceae: Pilgerodendron uvifera, Fitzroya cupressoides (French \& Tainter, 1973), Thuja plicata (Scheffer, 1957), and Cupressocyparis leylandii (Building..., 1972). When decaying data between cypress and pine is compared (Eslyn \& Highley, 1976; Peterson \& Cowling,1964), it is clear that cypress wood naturally has a technological advantage overcoming pine species. As expected, brown-rot caused more degradation than white-rot fungi.

\section{CONCLUSION}

General anatomical characteristics of cypress (Cupressus spp.) wood have shown that heartwood and sapwood is slightly distinct to distinct, and its color is brown moderate pale to white. The wood 


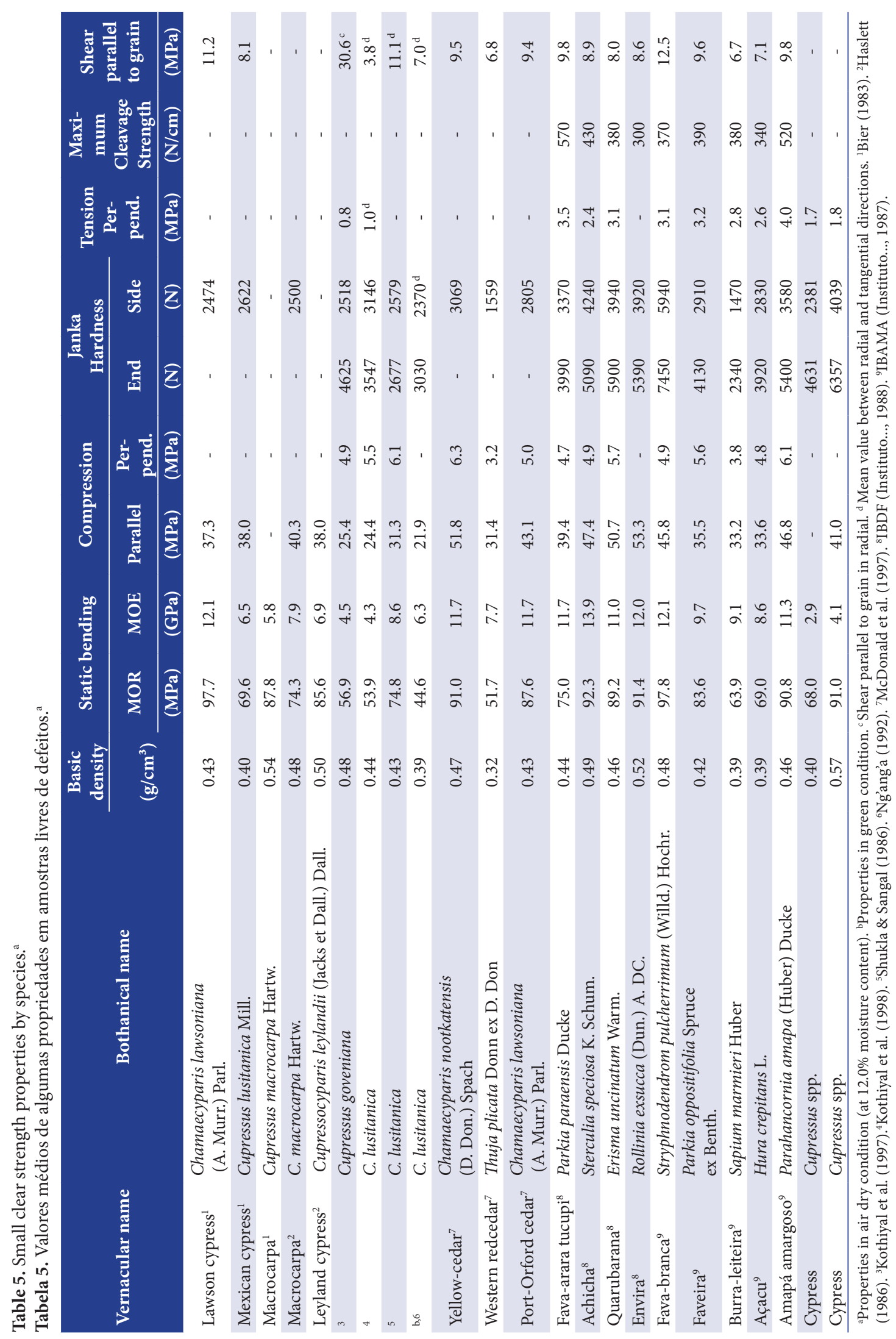


Table 6. Mass loss in a 12-week accelerated decay test of cypress wood exposed to G. trabeum (Persoon ex Fries) Murrill and T. versicolor (Linnaeus ex Fries) Pilat.

Tabela 6. Perda de massa, em ensaio acelerado de laboratório, de madeira de cipreste exposta aos fungos G. trabeum (Persoon ex Fries) Murrill e T. versicolor (Linnaeus ex Fries) Pilat.

\begin{tabular}{ccc} 
& Average mass loss (\%) \\
\hline Treatment & G. trabeum & T. versicolor \\
\hline Cupressus spp. & $1.08(1.44)^{\mathrm{a}}$ & $0.00(0.00)$ \\
\hline
\end{tabular}

Mean values of 12 samples. ${ }^{a}$ Number in parentheses are standard deviations.

has medium texture, straight grain and showed soft resistance to manual cross-cutting. It has a characteristic odor, very agreeable smell and the natural protective oil gives it an aromatic and durable scent.

Cypress is moderately light with basic density ranging from 0.40 to $0.57 \mathrm{~g} / \mathrm{cm}^{3}$. The ratio of tangential/radial shrinkage ranged from 1.3 to 1.8 , classifying the wood as moderately stable to unstable. When being processed, the wood showed very easy workability qualities using hand and machine tools. The wood should be suitable for high value interior joinery, furniture and turnery.

The percentage of extractive content was low and the lignin content was relatively high. These mean values were compatible to the chemical constituents of other softwoods species.

Cypress wood was "highly resistant" to the brown-rot fungus, G. trabeum, and white-rot fungus, T. versicolor.

Its light color, anatomical characteristics and easy processing, makes it comparable to some common and commercial hardwood and softwood species, mainly Pinus spp.

\section{ACKOWLEDGEMENTS}

We would like to extend our thanks to the technicians João E. Anacleto, Getúlio F. de Almeida, Luiz D. Santana and Ricardo P. de O. Santos. We are especially grateful to Maria H. M. G. de Figueiredo for her help.

\section{SUBMISSION STATUS}

Received: 04/03/2008

\section{CORRESPONDENCE TO}

\section{Esmeralda Yoshico Arakaki Okino}

Serviço Florestal Brasileiro - SFB, Laboratório de Produtos Florestais - LPF, Av. L 4 Norte, SCEN, trecho 2, lote 4, bloco B, CEP 70818-900, Brasília, DF, Brasil e-mail: esmeralda.okino@florestal.gov.br

\section{REFERENCES}

American Society for Testing and Materials - ASTM. ASTM D 143-94. Standard methods of testing small clear specimens timber. Annual Book of ASTM Standard. Philadelphia: ASTM; 1994.

American Society for Testing and Materials - ASTM. ASTM D 2017. Standard method of accelerated laboratory test of natural decay resistance of woods. Annual book of ASTM standard. Philadelphia: ASTM; 2005. v. 0410.

Bier, $H$. The strength properties of small clear specimens of New Zealand-grown timber. FRI Bulletin. New Zealand Forest Service 1983; 41:1-28.

Building Research Establishment - BRE. Laboratory tests of natural decay resitance of timber. Timberlab Papers. Princes Risborough Laboratory 1972; 50(1-28).

Camargos JAA, Coradin VTR, Czarneski CM, Meguerditchian I, Oliveira DD. Catálogo de árvores do Brasil. Brasília: IBAMA/DIREF/LPF; 2001.

Carvalho JS. A Cupressus lusitanica em São Paulo. Anuário Brasileiro de Economia Florestal 1954; 7(7):124142.

Clark JW. Natural decay resistance of fifteen exotic woods imported for exterior use. Madison: U. S.D.A., Forest Service; 1969. Research Paper FPL 103.

Coradin VTR, Muñiz GIB. Normas de procedimentos em estudos de anatomia de madeira: I Angiospermae. Série Técnica LPF 1991; 15:1-13.

Eslyn WE, HighleyTL. Decay resistance and susceptibility of sapwood of fifteen tree species. Phytopathology 1976; 66:1010-1017. doi:10.1094/Phyto-66-1010 
Foelkel CEB, Zvinakevicius C. Coníferas exóticas aptas para produção de celulose kraft II. Cupressus lusitanica. Belo Oriente; 1978.

French DW, Tainter FH. Comparative decay resistance of chilean woods. Forest Products Journal 1973; 23(8):49-51.

Greguss P. Identification of Living Gymnosperms on the basis of xylotomy. Budapest: Akadémiai Kiadó; 1955.

Guha SRD, Singh MM, Mathur GM, Sharma YH, Dhoundiyal SN. Utilisation of Cupressus cashmeriana for the production of kraft paper, writing and printing paper and newsprint. Indian Forester 1969; 95(9):640-649.

Guha SRD, Singh MM, Singh SV, Kumar S, Bist DPS. Kraft pulping of Cupressus lusitanica and Araucaria bidwilli. Indian Forester 1971; 97(9):542-546.

Haslett AN. Properties and utilisation of exotic speciality timbers grown in New Zealand. Part III: CYPRESSES. New Zealand Forest Service, FRI Bulletin 1986; 119:1-12.

Instituto Brasileiro de Desenvolvimento Florestal - IBDF. Madeiras da Amazônia: características e utilização. Estação Experimental de Curuá-Una. Brasília: IBDF; 1988.

Instituto Brasileiro do Meio Ambiente e dos Recursos Naturais Renováveis - IBAMA. Madeiras da Amazônia: características e utilização. Amazônia Oriental. Brasília: IBAMA/DIRPED/LPF; 1997. v. 3.

Jane FW. The structure of wood. $2^{\text {nd }}$ ed. London: Adam \& Charles Black; 1970.

Kothiyal V, Negi A, Rao RV, Gogate MG, Dakshindas SK. Assessment of wood quality of eighteen-year-old Cupressus goveniana from Maharashtra, India. Journal of Tropical Forest Products 1997; 3(2):186-193.

Kothiyal V, Negi A, Rao RV, Gogate MG, Dakshindas SK. Wood quality of eighteen-year-old Cupressus lusitanica from Maharashtra. Holz als Roh- und Werkstoff 1998; 32(2):119-127.

McDonald KA, Hennon PE, Stevens JH, Green DW. Mechanical properties of salvaged dead yellowcedar in southeast Alaska, Phase I. Madison, WI: U.S. Department of Agriculture, Forest Service, Forest Products Laboratory; 1997. Res. Pap. FPL-RP-565.

Munsell, C. Soil color charts. Baltimore: Koelmorgen, 1975.

Ng'ang'a F. Strength properties of cypress timber grown in Kenya. Commonwealth Forestry Review 1992; 73(227):186-192.

North Carolina State University - NCSU. Laboratorial instructions. Raleigh: Wood and Paper Department; 1989.

Okino EYA, Alves MVS, Teixeira DE, Souza MR, Santana MAE. Biodegradação de chapas de partículas orientadas de pinus, eucalipto e cipreste expostas a quatro fungos apodrecedores. Scientia Forestalis 2007a; 74:67-74.

Okino EYA, Camargos JAA, Santana MAE, Marques MHB, Martins VA, Sousa ME et al. Descrição dos caracteres tecnológicos da madeira de Cupressus glauca Lam. Scientia Forestalis 2006; 72:39-48.

Okino EYA, Pastore TCM, Camargos JAA, Alves MVS, Santos PHOS, Teixeira DE et al. Color variation of rubberwood clones and cypress infected by Gloeophyllum striatum and Phanerochaete chrysosporium. International Biodeterioration \& Biodegradation 2009; 63:41-45. PMCid:373060. doi:10.1016/j.ibiod.2008.04.004

Okino EYA, Resck IS, Cruz CLC, Santos PHO, Falcomer VAS. Evaluation of wood chemical constituents of Hevea brasiliensis and Cupressus decomposed by Gloeophyllum striatum using CP/MAS ${ }^{13} \mathrm{C}$ NMR and HPLC techniques. Journal of Tropical Forest Science 2010; 22(2):184-196.

Okino EYA, Santana MAE, Resck IS, Alves MVS, Falcomer VAS, Cunha JBM et al. Liquid chromatography and solid state $\mathrm{CP} / \mathrm{MAS}{ }^{13} \mathrm{C} \mathrm{NMR}$ techniques for chemical compound characterizations of cypress wood Cupressus glauca Lam. exposed to brown- and white-rot fungi. Carbohydrate Polymers 2008; 73:164-172.

Okino EYA, Souza MR, Santana MAE, Alves MVS, Sousa ME, Teixeira DE. Evaluation of the physical and biological properties of particleboard and flakeboard made from Cupressus spp. International Biodeterioration \& Biodegradation 2004; 53:1-5. doi:10.1016/j. carbpol.2007.11.019

Okino EYA, Souza MR, Santana MAE, Alves MVS, Sousa ME, Teixeira DE. Physico-mechanical properties and decay resistance of Cupressus spp. Cement-bonded particleboards. Cement \& Concrete Composites 2005; 27:333-338. doi:10.1016/j.cemconcomp.2004.02.046

Okino EYA, Teixeira DE, Del Menezzi CHS. Postthermal treatment of oriented strandboard (OSB) made from cypress (Cupressus glauca Lam.). Maderas. Ciencia y tecnologia 2007b; 9(3):199-210.

Okino EYA, Teixeira DE, Souza MR, Santana MAE, Alves MVS, Sousa ME. Propriedades de chapas OSB de Eucalyptus grandis e de Cupressus glauca. Scientia Forestalis 2008; 36(79):123-131.

Okino EYA, Teixeira DE, Souza MR, Santana MAE, Silva CBG, Tomaz RB, Sousa ME. Uso das madeiras de seringueira, pinus e cipreste na fabricação de chapas OSB. Floresta 2009; 39(2):457-468.

Paraskevopoulou AH. Variation of wood structure and properties of Cupressus sempervirens var. horizontalis in natural populations in Greece. IAWA Bulletin 1991; 12(2):195-206 
Pereira JCD, Higa RCV. Propriedades da madeira de Cupressus lusitanica Mill. Colombo: EMBRAPA CNPF; 2003. Comunicado Técnico, 107.

Peterson CA, Cowling EB. Decay resistance of extractive-free coniferous woods to white-rot fungi. Phytopathology 1964; 54:542-547.

Scheffer TC. Decay resistance of western redcedar. Journal of Forestry 1957; 55(6):434-442.

Shukla NK, Sangal SK. Preliminary studies on strength properties of some exotic timbers. The Indian Forester 1986; 112(5):459-465.
Tappi Test Methods. T $204 \mathrm{om}-88$. Solvent extractives of wood and pulp. Atlanta: Tappi technology Park; 1996c. v. 1 .

Tappi Test Methods. T 222 om-88. Acid-insoluble lignin in wood and pulp. Atlanta: Tappi Technology Park; 1996b. v. 1.

Tappi Test Methods. T 264 om 82. Preparation of wood for chemical analysis. Atlanta: Tappi technology Park; 1996a. v. 1.

United States Department of Agriculture - USDA. Wood handbook: wood as an engineering material. Washington; 1987. Agriculture handbook, 72. 